SMARO KamboURELI, born in Thessaloniki, Greece, came to Winnipeg in 1978 where she has lived since then. She is working on a genre study of the Canadian long poem and teaching at the University of Manitoba. Her first book, in the second person, was published in 1985. She has also co-edited a book of essays, $A$ Mazing Space: Writing Canadian Women Writing with Shirley Neuman.

\title{
It Was Not a Dark and Stormy Night
}

SMARO KAMBOURELLI

for Patrick Friesen

Theoria/theorein: not language degree zero; not empty signifiers; not things minus tissue; not tongue minus body. Behold. Be. Hold. Being a spectator. ${ }^{1}$

Theory: to contextualize the personal; to articulate the emotive; to retrieve the drowned self from within the self; to cry without guilt or shame; to talk about "me" without losing "my" privacy. How to hold away the fear of being found out."

The split between theory and writing (fiction/poetry) has often assumed the same configuration with the split between mind and body. ${ }^{3}$

1. How to make I-love-you synchronous with theorein. How to love the one in the many, how to love the many in the one.

2. Freud is not the name of my shadow.

3. The fissures are the same gaps producing the same silence there is no safety net for the writer there is no wall for the ladder to lean on. 
Theory as genre begets its own iconography. Yes, it does rehandle itself. ${ }^{4}$ Does theory (re)tell what the writer has left untold? Does it express without creating? Does it tell a parallel story?

4. over and over and over. again. and again. and then. now. before. tomorrow. there is no end. i've known that. there is no end of the inside of the body becoming a knot the shape of I-am-thinking of the mind reaching the hard core it didn't know it had. like the stone of a cherry. small but smooth but hard. like its name. sometimes it hurts. sometimes it doesn't. have you tried squeezing blood out of a stone? have you tongued the sharp edges of a rock idling on a beach?

5. the corner of grief. the corner of meditation. the corner of reading. of chewing my nails. of making love. of eating crackers and cheese preferably feta hard salty and white breathing through its tiny pores brie is second choice. the creased corner of the couch. holding me with patience. sometimes even with reverence. it is theorizing me. how to mother the abjected self. it doesn't matter if this is not theory. it still is. 
Theory often belongs to the genre of the fantastic. Its hesitation does not belong to the order of the real as the act of theorein reveals it to me. This is why I often translate myself into theoria, why I give my ambiguity the name of the uncanny. ${ }^{6}$

The self can never be theorized/thematized. It is what practises the act of theorein. The minute I start writing all precise margins are liquefied. The page is a littoral line. Solitude becomes the writing I's name. I is one and many. Skin touches nothing. Nothing touches it. I may even cease to exist. The $\mathrm{S}$ exits. The name becomes a signature. I cannot authorize or be authorized. The writer is the sumtotal of the residue of desire. The woman behind the writer has tasted desire at the moment of its death. There is no virginity in the history of beginnings. This woman is (still) (dying). ${ }^{7}$

6. This is not personal. I am not the $I$. This page is not a mirror. Mirrors are false exits. This page is a screen belonging both to the inside and to the outside. I'm just passing through. This page is the sieve that thins out the air I breathe. I dwindle into an otherness that cannot meet me. I theorô myself. Language rests on the tip of my tongue. Theoria weighs lightly on my eyelids.

$$
\text { eyes / tongue / language }
$$

the outside / what tastes the image (eïdolon) / the taste The fictionality of theory; the truth of fiction.

7. How many times have I gone through this. Untying the naughts. Attempting the impossible. Pain is good for you, little one. The voice a cherry stone. The lips the delicate lines of lust without object. My heel a warm, unwanting fist inside the hand. (The the defines the bitter taste of my theorein in the feminine.) I've dreamt of sacrificing dreams to the altar of desire. I've dreamt of Nike's face - an icon of terror. I've slept on the same marble bed with Louvre's Hermaphroditus. I no longer love myself. I could be any woman. I am not an enigma. I could change places with my double - if only I knew where to find her. I could even be myself. 
I've been told I'm Electra. It was in a damp basement apartment lit with the cold light of a bare bulb. I ran out and down the steep street and when I reached the university campus I was out of breath, my limbs shaking. It was a matter of theory, only I didn't know this at the time. That night I remembered that someone (my aunt?) had taken me to see Kakoyannis' Electra when I was a child. Eirini Pappas' classic face leaning over the ground; her cutting her hair off, the gesture of mourning. This mythic scenario is now one of my recurring daydreams. Only I don't know whether I mourn mother, father, brother, lover or my own death. ${ }^{8}$

Theory and fiction are each other's doubles. "Narcissistic narratives." 9

8. Death has no face. Occasionally, it takes the shape of an endless sentence, its length extended by nots. A rope of words binding nothing. A figure without body. It could be desire. It could be the image of freedom. It could be dying. It could be love.

9. Even though my words may have turned against me, this is not the story of femina vita. 
Theory and writing. Their intercourse is the paradigm of my life as long as it avoids overdetermination. As long as it doesn't try to beget my other. ${ }^{10}$ Do-be-do-be-do. ${ }^{0}$

10. This is both theory and praxis. (Rhetoric is not a source of theory.) 